\title{
アセトアセチル化 PVA の木材接着剤への適用 The Application of Acetoacetylated PVA to the Adhesive for Wood
}

\section{山田 雅 章* Masaaki YAMADA}

\section{1.はじめに}

シックハウス症候群が社会問題となる中, 非ホルムアル デヒド系接着剤として水系エマルション接着剤が注目され ている。水系エマルションは踈水性の合成樹脂が水溶性の 保護コロイドや界面活性剤を介して水中に分散しており, 溶剤形のものに比べて取り扱い易いことや比較的安価なこ とが特徵である。水系エマルション接着剤の代表的なもの として酢酸ビニル樹脂エマルションがある。このエマルショ ンの保護コロイドには多くの場合ポリビニルアルコール (PVA）が使用される1)。しかし，PVA は分子中に水酸基 を多数保有するため, この水酸基が水の吸着点となり成膜 後の耐水性に欠けることが知られている。よって PVA を 保護コロイドとしたエマルション接着剤は, 一液型では耐 水性の要求される用途にはほとんど使用されていない。

最近, PVA 側鎖の一部にアセトアセチル (AA) 基を導 入した $\mathrm{AA}$ 化 PVA が登場し，水系エマルション接着剤の 保護コロイドとして一部検討されている。またこの PVA は最近需要が伸びている2) 水性高分子ーイソシアネート系 接着剤（API）の主剤成分としての利用も期待されており, 検討例屯見られる

ここでは AA 化 PVA の特性を解明し木材用接着剤への 適用を検討するため, PVAの重合度, 疎水基量, 疎水基 の分布状態を示すブロックキャラクター等の条件を变えた 一般 PVA および AA 化 PVA を用いて，イソシアネート 化合物（pMDI）を添加した際の PVA 水溶液やフィルム の特性および木材接着性能を評価する ${ }^{6 \sim 8)}$ とともに， AA 化 PVA を保護コロイドに用いた酢酸ビニル樹脂エマルショ

* 静岡大学農学部

静剛市駿河区大谷 836 于 $422-8529$

Faculty of Agriculture, Shizuoka University 836 Ohya Suruga-ku Shizuoka 422-8529 JAPAN

(平成 19 年度日本接着学会進歩賞受賞)
ン（EPVAc）を合成し，その接着剂物性と木材接着性能 について従来の EPVAc と比較した結果 ${ }^{9)}$ を紹介する。

\section{AA 化 PVA とは}

PVA の側鎖に AA 基を導入したものが $\mathrm{AA}$ 化 PVA で ある10（図 1)。AA 基は溶液中ではケト・エノール互变 異性体として存在しており, 水のような極性溶媒中ではケ 卜型が多く，気相や無極性溶媒中ではエノール型が多くな るといわれている11)。本研究では水を溶媒として用いたた め $\mathrm{AA}$ 基はケト型として存在していると思われ，ケト型 $\mathrm{AA}$ 基の活性メチレン部分が架橋反応に寄与すると考えら

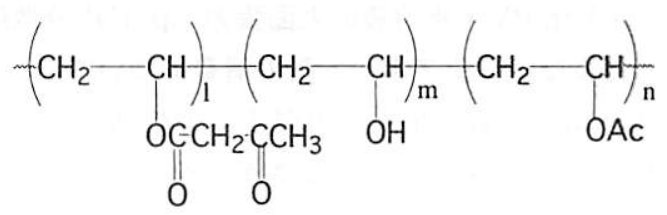

図 1 アセトアセチル化PVA

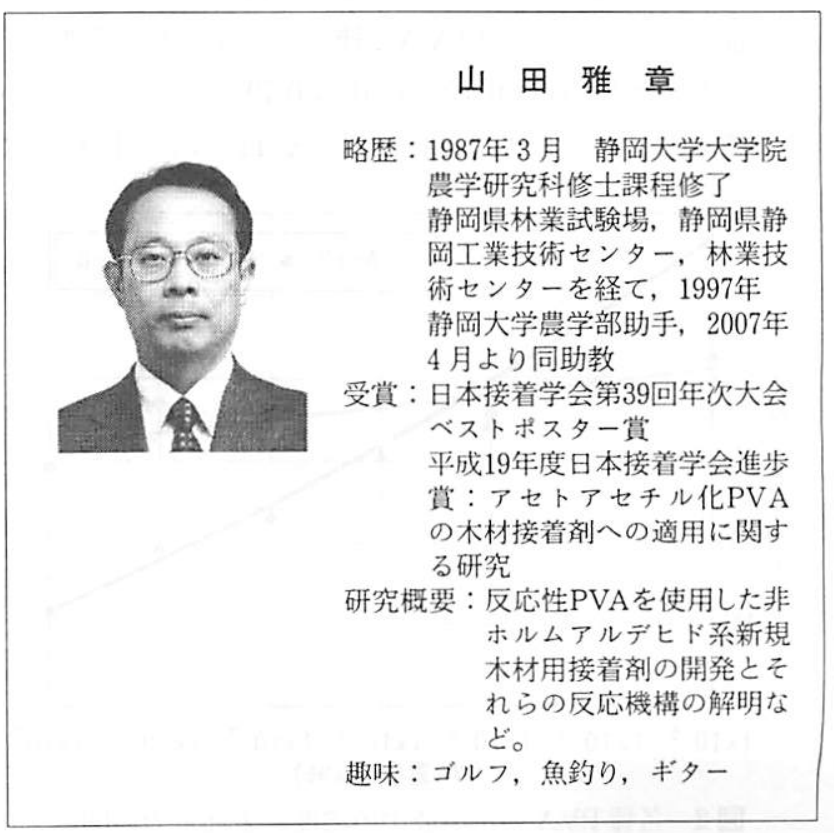


れる。AA 化 PVA は加熱により自己架橋やセルロース中 の水酸基と反応すると考えられ，木材接着系においてより 高い接着強さが得られる可能性がある11)。

\section{AA 化 PVA の pMDI との反応と木材接着性能}

\section{1 供試 PVA}

表 1 に示す PVA を蒸留水で溶解し, 水溶液として使用 した。PVAの重合度は 1100 とし, 一般に行われるアル カリケン化により疎水基の分布をブロック状とした PVA (11-B) と, 一旦完全ヶン化した後, 再酢化を行って意図 的にブロック性を低下させた（ランダムに近い状態） PVA (11-R) および AA 化 PVA を用いた。なお，PVA 中の 疎水基の分布状態を知る指標として，一般の二元重合体で 用いられるブロックキャラクター $\eta$ を用いた ${ }^{12) 。}$
べて界面活性能が高い上考えられる。一方，A-10（ $\eta=$ 0.67) と $11-\mathrm{B}$ とを比較すると， A-10 はブロックキャラ クターが大きいにも関わらず，この水溶液の表面張力は大 きく低下し $11-\mathrm{B}$ と同程度の值を示した。表面張力を低下 させる要因は, 重合度が同程度の場合, 主にブロックキャ ラクターと疎水基量である。雨 PVAにおいて疎水基量は A-10 が多い反面, ブロックキャラクターは $11-\mathrm{B}$ が小さ い。よって, これらが相殺されてほぼ同程度の界面活性能 を示したものと考えられる。

油状成分である pMDI をPVA 水溶液に添加した際 の分散性能を検討するために，乳化性評価装置 M100 （LASENTEC 社）を用いて PVA 水溶液中に分散した pMDI 粒子のコード長（液滴の大きさを示す指標）および カウント数（液滴の総数）を測定した。本報では主として

表 1 供試 PVA

\begin{tabular}{ccccccc}
\hline PVA & $\begin{array}{c}\text { AA 基量 } \\
(\mathrm{mol} \%)\end{array}$ & $\begin{array}{c}\text { OAc 基量 } \\
(\mathrm{mol} \%)\end{array}$ & $\begin{array}{c}\text { 疎水基量 } \\
(\mathrm{mol} \%)\end{array}$ & $\begin{array}{c}\text { 水酸基量 } \\
(\mathrm{mol} \%)\end{array}$ & $\begin{array}{c}\text { ブロック } \\
\text { キャラクター }\end{array}$ & 重合度 \\
\hline 11-R & 0 & 7.1 & 7.1 & 92.9 & 0.79 & 1100 \\
$11-\mathrm{B}$ & 0 & 8.4 & 8.4 & 91.6 & 0.47 & 1100 \\
\hdashline $\mathrm{A}-5$ & 4.9 & 0.5 & 5.4 & 94.6 & 0.79 & 1100 \\
$\mathrm{~A}-6$ & 6.1 & 0.5 & 6.6 & 93.4 & 0.81 & 1100 \\
$\mathrm{~A}-8$ & 7.9 & 0.5 & 8.4 & 91.6 & 0.68 & 1100 \\
$\mathrm{~A}-10$ & 10.2 & 0.5 & 10.7 & 89.3 & 0.67 & 1100 \\
\hline
\end{tabular}

\subsection{AA 化 PVA 水溶液の表面張力, pMDI 分散能 およびィソシァネート基の消費について}

PVA 水溶液の表面張力は円環法により測定した。円環 はメタノール，超純水で十分に洗浄した白金リングを使用 した。測定の結果（図 2), A-10 と 11-B は水溶液濃度が 高くなると表面張力の低下が大きく，11-R に比べて低い 表面張力を示した。一般 PVA 2 種のブロックキャラクター を比較すると $11-\mathrm{B}$ は $0.47,11-\mathrm{R}$ は 0.79 である。したがっ て酢酸基がブロック状に存在している 11-B は 11- R と比

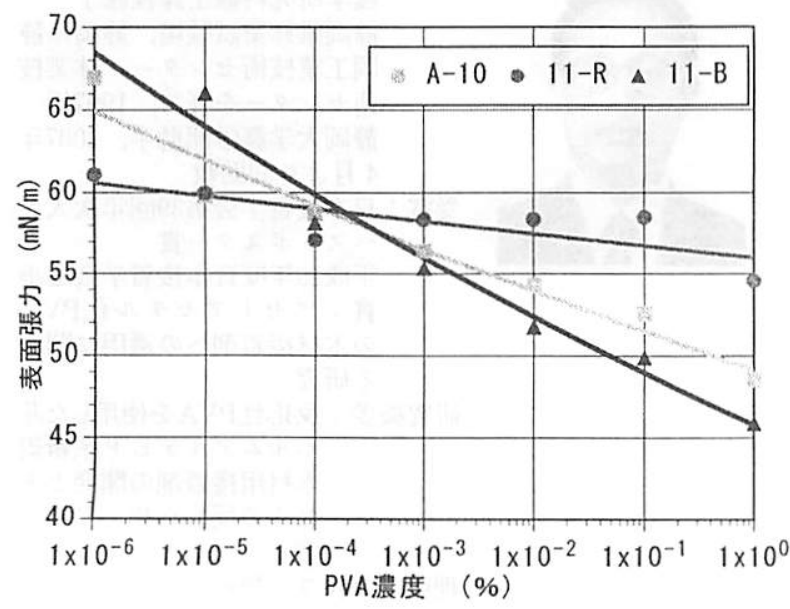

図 2 各種 PVA の水溶液中の莀度と表面張力の関係
コード長によって分散性能の良否を評価した。図 3 には, 各PVA の $5 \%$ 水溶液へpMDI を添加した際の平均コード 長の経時变化を示す。pMDI の添加量は, pMDI 中のイソ シアネート（NCO）基と PVA 中の $\mathrm{OH}$ 基（AA 基も含む） との比 (pMDI 添加比) で 0.2 とした。11-B と 11-R と を比較した場合，ブロックキャラクターが小さい11-Bの 方が良好な分散性を示した。ブロックキャラクターが小さ いPVA ほど界面活性能が高く, pMDI の粒子をより微細

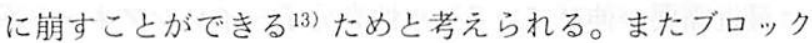
キャラクター，粘度ともに近い值を示した $11-\mathrm{R}$ と A-6 とを比較すると，A-6の方が明らかに良好な分散性を示

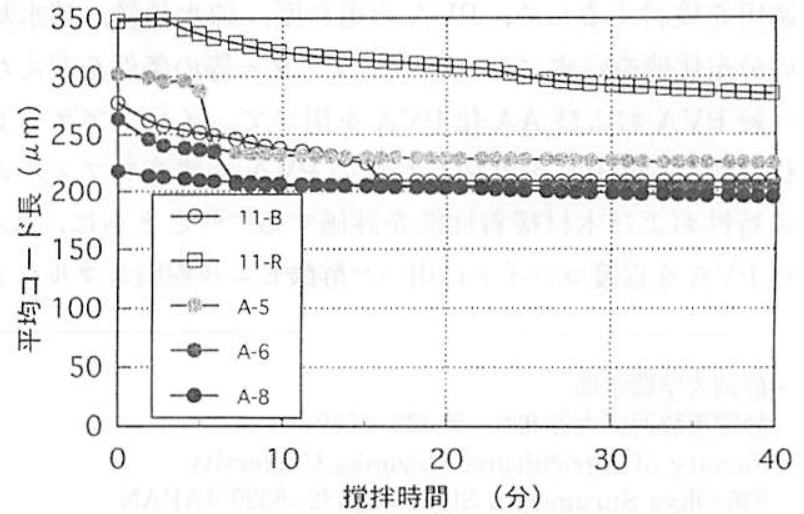

図 3 各種PVAの $5 \%$ 水溶液における pMDI の分散性能 


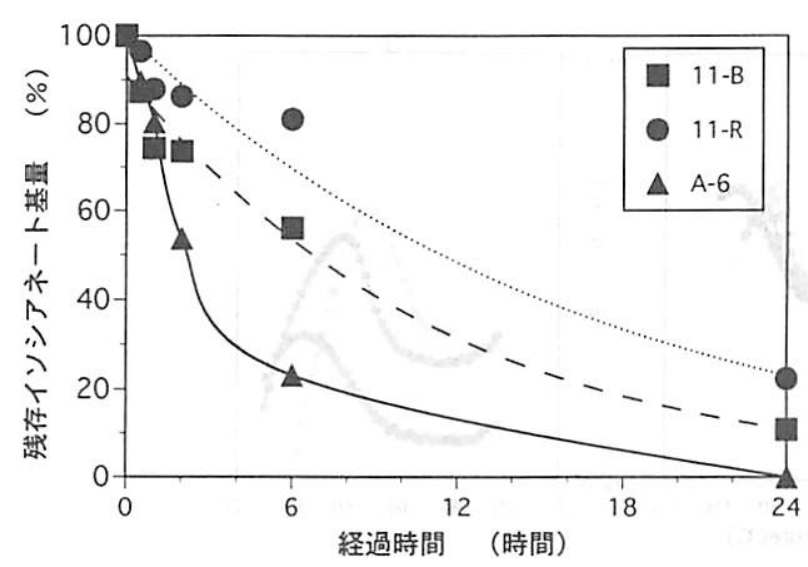

図 4 各種 PVAの $5 \%$ 水溶液中における 残存イソシアネート基量の経時変化

した。このことから疎水基量, ブロックキャラクターが近 い值であっても酢酸基に比べて AA 基の方が pMDI の分 散性能に優れていることがわかる。

PVA $15 \%$ 水溶液に添加比 0.2 となるように pMDI を加 え, 残存 $\mathrm{NCO}$ 基の定量をジブチルアミン塩酸法 ${ }^{14)}$ を用 いて行った。混合直後の NCO 基量の值を $100 \%$ として相 対的な $\mathrm{NCO}$ 基の残存量を算出し，それらを図 4 に示す。 11-R に比べてブロックキャラクターが小さい11-Bの方 が NCO 基の消費が速い。A-6 は疎水基量およびブロッ クキャラクターが $11-\mathrm{R}$ とほぼ同じであるが，2 時間後に は 11-R および 11-B に比べて NCO 基残存量が大幅に減 少した。さらに $11-\mathrm{B}$ と $11-\mathrm{R}$ は 24 時間で pMDI が完全 に消費できなかったのに対して，A-6 は NCO 基残存量 が $0 \%$ に達した。これは側鎖に存在する $\mathrm{AA}$ 基の活性メ チレンと pMDI との反応が起こり, その消費が促進され たためと推察される。したがって，11-BとA-6 は表面 張力を低下させる能力は同程度であるが，11-Bにはない 反応性により $\mathrm{A}-6$ は良好な pMDI 分散性を有すること が考えられる。そのためブロックキャラクターが大きく疎 水基のブロック性が低い状態で存在しているにあかかわら
ず，11-B 以上の pMDI との反応性を有するものと思われ る。

\section{3 接着剂フィルムの動的粘弾性と架橋密度}

pMDI 添加比を变化させて作製した 11-Rの眝蔵弾性率 E’は，高温域における低下が比較的大きく，またゴム状 平坦部の值も低かった（図 5)。一方，11-B は高温域での E’の低下が小さく, ゴム状平坦部の值も比較的高かった。 A-6では更にこれが顕著で，ゴム状平坦部の E’が高い值 を示した。ゴム状平坦部の $\mathrm{E}$ '值は架橋密度を反映してい るため，11-B や A-6 では架橋密度が 11-R と比べて高 くなっていることが推察される。

次に, 3 種類の PVA の損失弾性率 E” を図 6 に示す。 11-R ではどの pMDI 添加比においてもピークの形状はか なりシャープで，また添加比が増加してもピークの高温側 へのシフトはそれほど大きくなかった。一方，分散性が良 好であった A-6 では pMDI 添加比が増加するほどピーク の形状がブロードとなった。A-6は pMDI 添加比が 1 に なると末添加と比較して E”ピークシフト量が全サンプル

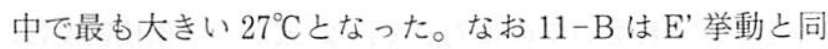
様に 11-R と A-6 の中間的挙動を示した。

架橋によるガラス転移温度のずれから，おおよその架橋 密度を算出することが可能であるといわれ，以下に示す Nielsen の経験式がある ${ }^{15)}$ 。

$$
\mathrm{Tg}-\mathrm{Tg}_{0} \fallingdotseq 3.9 \times 10^{4} \times \nu
$$

$\mathrm{Tg}$ : 架橋した重合体の E” ピーク温度

$\mathrm{Tg}_{0}$ : 架橋を持たない重合体の $\mathrm{E} ”$ ピーク温度 $\nu:$ 架橋密度 $\left(\mathrm{mol} / \mathrm{cm}^{3}\right)$

また，ゴム弾性理論により弾性率 (E') と架橋密度の関 係が近似的に以下のように導かれる ${ }^{16)}$ 。

$$
\mathrm{E}^{\prime} \fallingdotseq \frac{3 \mathrm{dRT}}{\mathrm{Mc}} \fallingdotseq 3 \nu \mathrm{RT}
$$

$\mathrm{E}^{\prime}$ : ゴム状平坦部における眝蔵弾性率 (a)

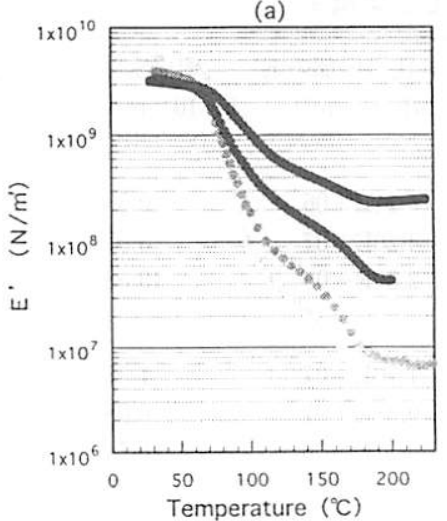

(b)

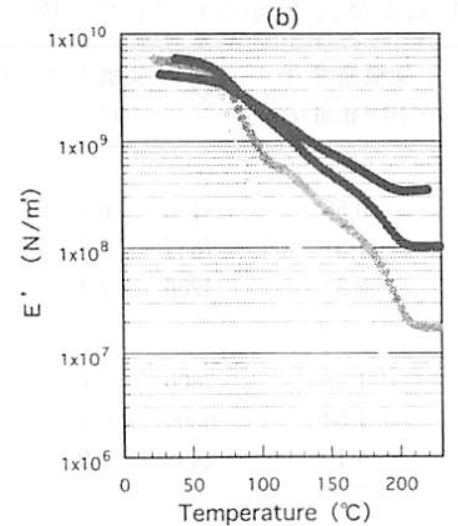

(c)

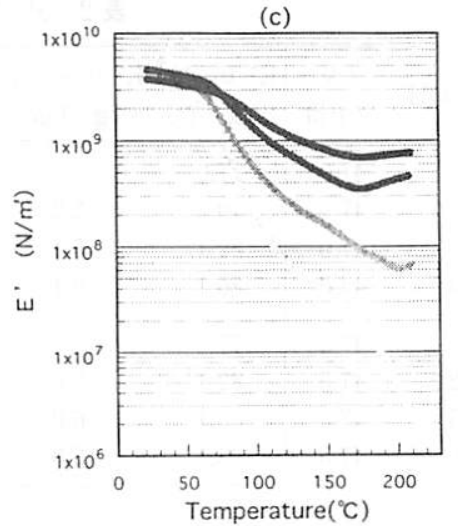

図 5 pMDI を添加して $120^{\circ} \mathrm{C} て ゙ 2$ 時間加温した各種 PVA フィルムの貯蔵弾性率

(a) $11-\mathrm{R}$, (b) $11-\mathrm{B}$, (c) $\mathrm{A}-6$

$\mathrm{NCO} / \mathrm{OH}=0, \bullet 0.2, \bullet 0.5, \bullet 1.0$ 

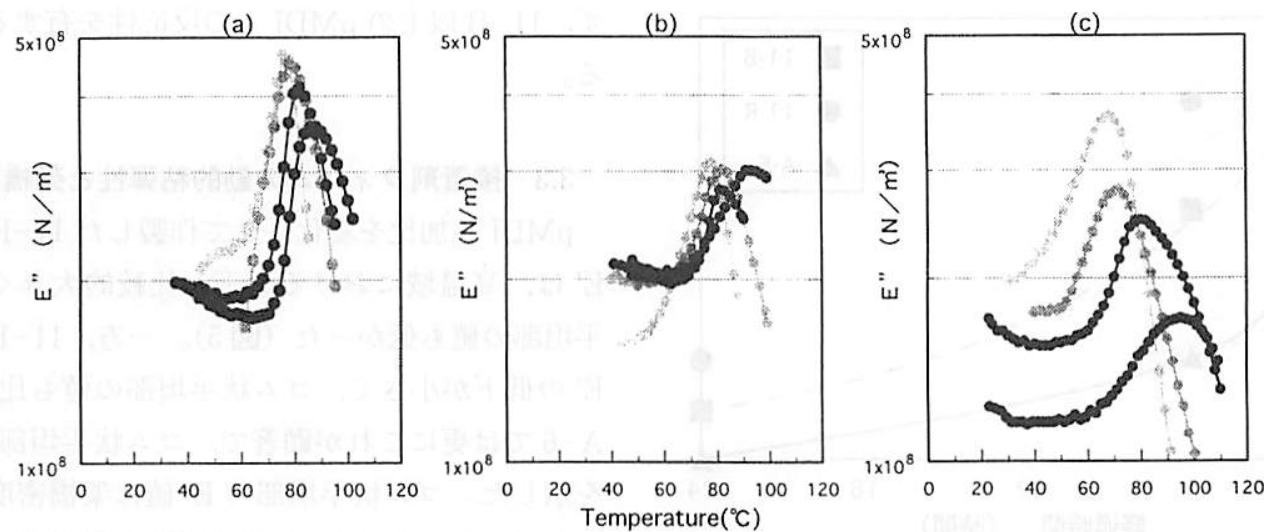

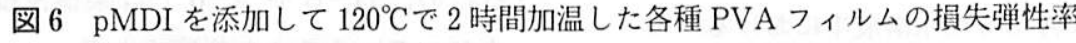

(a) $11-\mathrm{R}$, (b) $11-\mathrm{B}$, (c) $\mathrm{A}-6$ $\mathrm{NCO} / \mathrm{OH}=0,0.2$,

- 1.0

\section{$\mathrm{d}$ : 密度 \\ $\mathrm{R}:$ 気体定数 \\ $\mathrm{T}:$ 絶対温度 \\ $\mathrm{Mc}$ : 架橋点間分子量 \\ $\nu:$ 架橋密度 $\left(\mathrm{mol} / \mathrm{cm}^{3}\right)$}

(1) 式から算出した架橋密度はポリマーの架橋によるす のと考えられているのに対して，(2)式からの架橋密度は， ポリマーの架橋や絡み合いと pMDI と水の反応によって できる $\mathrm{NCO}$ 誘導体の効果が重なって算出される $\left.{ }^{17}\right)$ 值と考 えられる。NCO 誘導体の効果によりゴム状平坦部におけ る $\mathrm{E}^{\prime}$ 值が上昇する ${ }^{18)}$ ため, (2) 式を用いて架橋密度を算出 すると, 実際のポリマーの架橋密度よりも高い值が算出さ れる。A-6 は (2) 式で計算した架橋密度の值が大きく, pMDI 添加比が 1 のとき $11-\mathrm{R}$ と比べて 3 倍以上の架橋密 度が得られた。分散性試験により A-6 が良好な結果を示 したことから，A-6 水溶液中では $\mathrm{AA}$ 基の存在によって pMDI の粒子が細かく分散し液滴の総表面積が増大するこ とによって PVA ポリマーと pMDI との反応, および水 と $\mathrm{pMDI}$ との反応が促進され，そのほとんどが有効に反 応したことが考えられる。また, 分散性がほぼ同程度であっ
た 11-B と比較しても A-6 が良好な結果を示したのは， 前述したように $\mathrm{AA}$ 基の有する反応性の高さが影響して いるものと思われる。

各 PVAについて, 側鎖に存在する官能基 $(\mathrm{OH}$ 基, $\mathrm{AA}$ 基）の中で架橋反応に関与した官能基の割合（表 2 の架橋 率）をPVAの架橋点間分子量 $(\mathrm{Mc})$ とモノマー分子量 の関係から算出しここれらを(1) 式および (2) 式から算出し た架橋密度の值とともに表 2 に示す。pMDI 添加比 0.2 て はどの PVAにおいても (1) 式から算出された架橋率はそ れほど変わらなかった。しかし，添加比が高くなると11B，A-6 のように分散性の良い PVA ほど架橋率は高くなっ た。重合度，ブロックキャラクターが同程度である $11-\mathrm{R}$ と A-6 を比較すると, $\mathrm{A}-6$ は $11-\mathrm{R}$ と比べて $2 \sim 4$ 倍の 架橋率を示した。油状成分分散性の低い PVA を用いると, その水溶液中では pMDI は大きな液滴となり, 水やPVA と十分な反応が起こらないため，そのままの状態で接着剤 皮膜中に残存すると考えられ，架橋㓮としての役割を効果 的に果たしているとは言い難い。言い換えれば, pMDI 分 散性の良好な PVA を主剤成分として使用すれば，高価な pMDI の添加量を減少させることが可能であると思われる。

表 2 式 (1) および式 (2) から算出した架橋密度と架橋率

\begin{tabular}{|c|c|c|c|c|c|c|c|c|c|c|c|}
\hline PVA & $\mathrm{NCO} / \mathrm{OH}$ & $\begin{array}{l}\text { モノマ- } \\
\text { 分子量 }\end{array}$ & $\begin{array}{l}\text { E” ピーク } \\
\text { 温度 }\left({ }^{\circ} \mathrm{C}\right)\end{array}$ & $\begin{array}{l}\text { E” ピーク差 } \\
\text { (Tg-Tgo) }\end{array}$ & $\begin{array}{c}\text { 架橋密度 (1) } \\
\left(\times 10^{-4} \mathrm{~mol} / \mathrm{cm}^{3}\right)\end{array}$ & $\mathrm{Mc}$ & $\begin{array}{c}\text { 架橋率 (1) } \\
\text { (\%) }\end{array}$ & $\begin{array}{c}\text { ゴム状平坦部の } E^{\prime} \\
\quad\left(\text { dyne } / \mathrm{cm}^{2}\right)\end{array}$ & $\begin{array}{c}\text { 架橋密度 (2) } \\
\left(\times 10^{-4} \mathrm{~mol} / \mathrm{cm}^{3}\right)\end{array}$ & $\mathrm{Mc}$ & $\begin{array}{c}\text { 架橋率 (2) } \\
\text { (\%) }\end{array}$ \\
\hline \multirow{4}{*}{$11-\mathrm{R}$} & 0 & 47.0 & 77.0 & - & - & - & - & - & - & - & - \\
\hline & 0.2 & 47.0 & 79.2 & 2.2 & 0.55 & 18140 & 0.3 & $6.11 \mathrm{E}+06$ & 0.50 & 20200 & 0.2 \\
\hline & 0.5 & 47.0 & 82.1 & 5.1 & 1.31 & 7647 & 0.6 & $4.20 \mathrm{E}+07$ & 3.57 & 2798 & 1.7 \\
\hline & 1.0 & 47.0 & 86.1 & 9.1 & 2.33 & 4286 & 1.1 & $2.30 \mathrm{E}+08$ & 19.58 & 511 & 9.2 \\
\hline \multirow{4}{*}{$11-B$} & 0 & 47.5 & 77.1 & - & - & - & - & - & - & - & - \\
\hline & 0.2 & 47.5 & 82.1 & 5.0 & 1.28 & 7800 & 0.6 & $1.70 \mathrm{E}+07$ & 1.37 & 7311 & 0.6 \\
\hline & 0.5 & 47.5 & 83.1 & 6.0 & 1.54 & 6500 & 0.7 & $9.88 \mathrm{E}+07$ & 8.05 & 1243 & 3.8 \\
\hline & 1.0 & 47.5 & 93.1 & 16.0 & 4.10 & 2438 & 1.9 & $3.21 \mathrm{E}+08$ & 26.74 & 374 & 12.7 \\
\hline \multirow{4}{*}{$A-6$} & 0 & 51.9 & 68.1 & - & - & - & - & - & - & - & - \\
\hline & 0.2 & 51.9 & 72.1 & 4.0 & 1.03 & 9750 & 0.5 & $6.16 \mathrm{E}+07$ & 5.19 & 1928 & 2.7 \\
\hline & 0.5 & 51.9 & 81.1 & 13.0 & 3.33 & 3000 & 1.7 & $3.51 \mathrm{E}+08$ & 31.33 & 319 & 16.3 \\
\hline & 1.0 & 51.9 & 95.1 & 27.0 & 6.92 & 1444 & 3.6 & $6.95 \mathrm{E}+08$ & 61.89 & 162 & 32.1 \\
\hline
\end{tabular}




\section{4 木材接着性能}

pMDI 添加比の違いによる接着強さおよび木破率を図 7 に示す。どのPVAについても常態における接着強さは, pMDI 添加比が 0.2 以上ではほぼ横ばいとなった。また PVAの違いによる接着強さの差はあまりみられなかった。 木破率は pMDI 添加比の増加に伴い上昇し, さらに分散 性試験において良好な結果を得た PVA ほど高い値を示し た。室温水浸せき処理後の接着強さは全体的に低下したも のの, pMDI 添加比の増加に伴い上昇した。また, 分散性 が良好であった A-6 は湿潤時においても高い接着強さを 示した。木破率はほとんどの試験片で $0 \%$ に近い值であっ たが，A-6の pMDI 添加比 1 においては $60 \%$ 上で上昇し, このことからも AA 基が効果的に pMDI と反応したことが 推察される。これらの試験結果は分散性, および接着剤フィ ルムの架橋密度の結果とよく一致した傾向を示している。 pMDI 分散性の良好な PVA を接着剤として使用すれば, 高い架橋密度が得られるため, 湿潤状態であ PVA が可塑 化されにくい。よって接着試験時の温度における弾性率を 比較的高く保持でき, 結果として pMDI の添加量を少な くしても良好な耐水接着性能が得られるものと思われる。

\section{AA 化 PVA を保護コロイドに使用した 酢酸ビニル樹脂エマルションについて}

水系エマルション接着剤は, 保護コロイド中に疎水性の 合成樹脂が包まれて, これが水中に分散するという構造を している。EPVAcの場合, その保護コロイドにはPVA

(a)
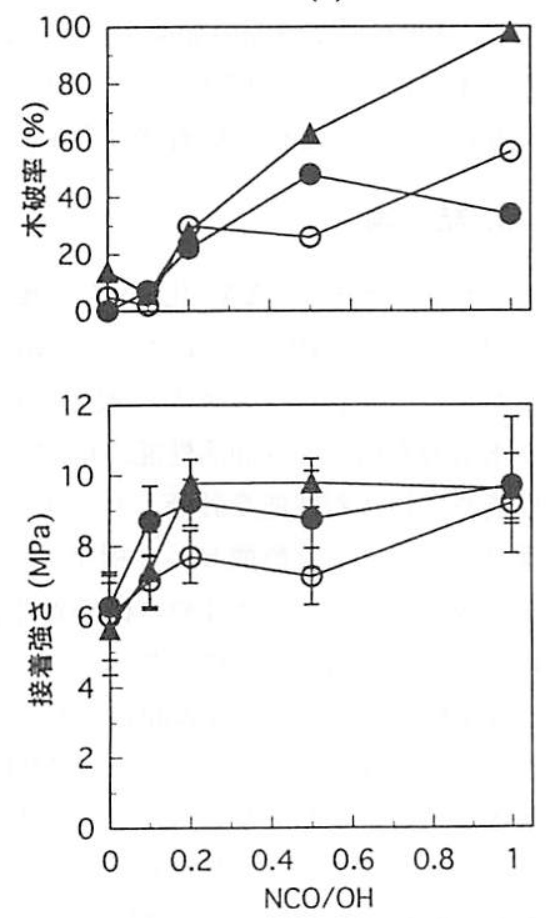

が一般に使用されている11。しかし, PVAは水溶性ポリ マーであり, 接着層が水に触れると PVA 成分が溶解した り接着層が容易に可塑化されるため,これを保護コロイド に用いた EPVAc は耐水性が極めて低い。ここでは, AA 化PVA を保護コロイドに使用した EPVAc を合成し, 加 熱処理による接着剤物性の変化やそれによる木材接着性能 の改善効果等を従来の EPVAc と比較検討した ${ }^{9)}$ 。

\subsection{EPVAc の動的粘弾性}

AA 化 PVA を使用した EPVAc を 2 種類 (A10, A20) と一般 PVA を使用した EPVAc（N10） 1 種類の合計 3 種類の接着剤を合成して使用した。エマルションの合成は 3 段階で行い，開始剂には過硫酸アンモニウム（APS）を 用いた。作製した接着剤の詳細を表 3 に示す。

図 8 に $20^{\circ} \mathrm{C} 7$ 日養生後の $\mathrm{A} 10, \mathrm{~N} 10$ の動的粘弾性を示 す。両サンプルとあ $50^{\circ} \mathrm{C}$ 付近になると $\mathrm{E}$ ”はピーク（図 8 中の a)を示し,これに伴って E’が急激に低下した。これ らは酢酸ビニル樹脂 (PVAc) のガラス転移に伴う变化で ある。また, $70^{\circ} \mathrm{C}$ 付近には非常に小さいながら PVAのガ

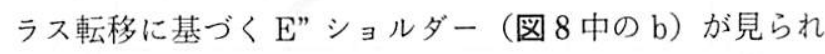
る。このショルダーは $\mathrm{N} 10$ の方が若干大きいものの $20^{\circ} \mathrm{C}$ 7 日養生においては A $10, \mathrm{~N} 10$ とも粘弾性的にはほぼ同様 の挙動を示した。なお， $20^{\circ} \mathrm{C}$ 養生の期間を 10 ヶ月まで延 長し，長期放置による架橋反応の検討を行った結果，A10 では 14 日目になるとわずかに E' の高温部にゴム状平坦部 が見られるようになり，10ヶ月後になるとこの平坦部の

(b)
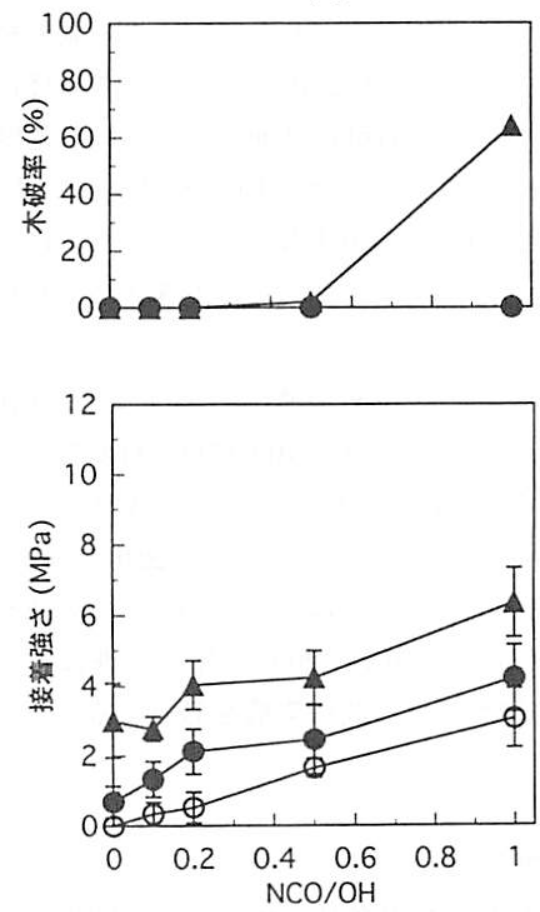

図 $7120^{\circ} \mathrm{C}$ で 2 時加温した試験片によるイソシアネート添加比と木材接着性能の関係 (a) : 常態, (b) : 室温水浸せき 11-B, $\bigcirc 11-\mathrm{R}, \boldsymbol{\Delta} \mathrm{A}-6$ 
表 3 供試酢酸ビニル樹脂エマルションの特性

\begin{tabular}{cccccc}
\hline エマルジョン & $\mathrm{PVA}$ & $\mathrm{PVA} / \mathrm{VAc} /$ 水 & 固形分 & $\mathrm{pH}$ & $\mathrm{PVA}$ 含量 \\
\hline $\mathrm{A} 10$ & $\mathrm{Z}-210^{* 1}$ & $5 / 41 / 54$ & $45.3 \%$ & $3.6 \sim 3.8$ & $11.0 \%$ \\
$\mathrm{~A} 20$ & $\mathrm{Z}-210^{* 1}$ & $8 / 32 / 60$ & $38.4 \%$ & $3.6 \sim 3.8$ & $20.8 \%$ \\
\hdashline $\mathrm{N}_{10}$ & $\mathrm{GM}-14 \mathrm{~L}^{* 2}$ & $5 / 41 / 54$ & $45.2 \%$ & 4.0 & $11.0 \%$ \\
\hline
\end{tabular}

* 1: AA 化 PVA，ケン化度 $96.1 \mathrm{~mol} \%$ ((勅) 日本合成化学工業製)

*2：一般 PVA，ケン化度 $87.7 \mathrm{~mol} \%$ （侏) 日本合成化学工業製）

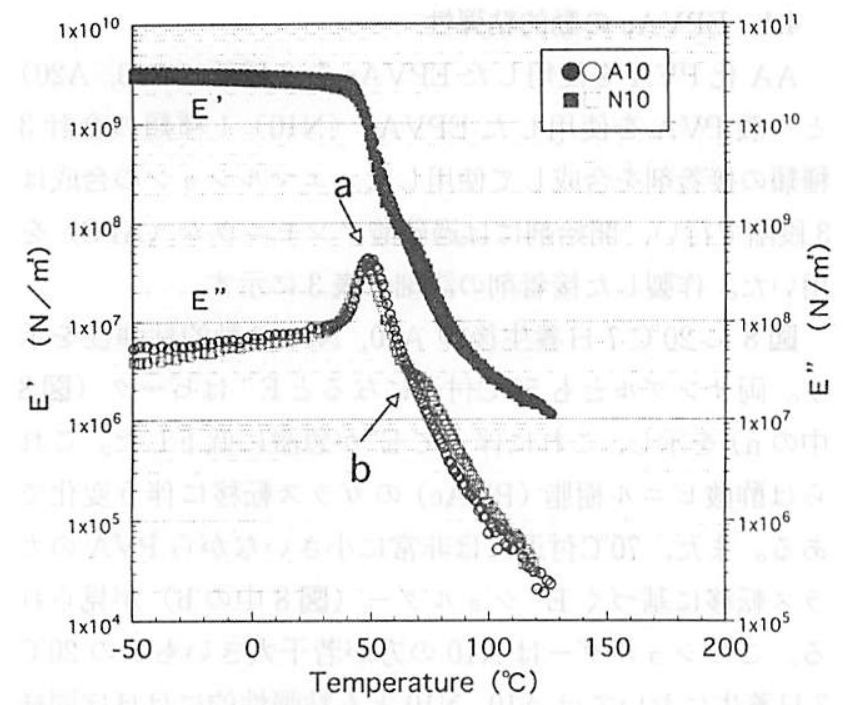

図 $820^{\circ} \mathrm{C} て ゙ 7$ 日間養生した $\mathrm{A} 10$ および $\mathrm{N} 10$ フィルムの 動的粘弾性

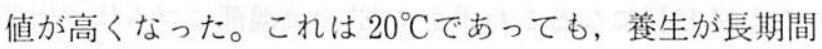
になれば AA 化 PVA の架橋が徐々に進行するためと考え られる。

図 9 には $120^{\circ} \mathrm{C} て ゙ 2$ 時間加温処理したフィルムの動的粘 弾性を示す。 $50^{\circ} \mathrm{C}$ 付近に出現する PVAc のガラス転移に

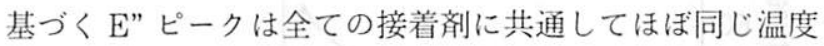
に出現したが, A20 はPVA 量が他 2 種の EPVAc の約 2 倍である反面, PVAc 量はその分少ないので, それらに対 応した E”ピーク（またはショルダー）の大きさにも変化 が認められた。

PVAのガラス転移に基づくE” 挙動に注目すると, N10

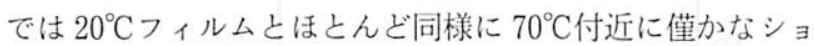
ルダー（図 9 中のb1）が認められた。しかし A10ではこ の E” ショルダーが $30^{\circ} \mathrm{C}$ 以上高温側にシフト（図 9 中の b2） し, これに伴い $70^{\circ} \mathrm{C}$ 以上の高温域において $\mathrm{E}$ ’が高い值を 示した。このことから, $\mathrm{A} 10$ は $120^{\circ} \mathrm{C}$ の加温処理により $\mathrm{AA}$ 基が反応し接着剤ポリマー間に架橋を形成することが 考えられる。

\section{2 木材接着性能}

図 10 に試験片作製時の加温条件と接着性能の関係を示 す。全ての加温条件において常態の接着強さ, 木破率は同 等であり，11〜 $12 \mathrm{MPa}$ の接着強さと 50 〜 $80 \%$ の木破率を

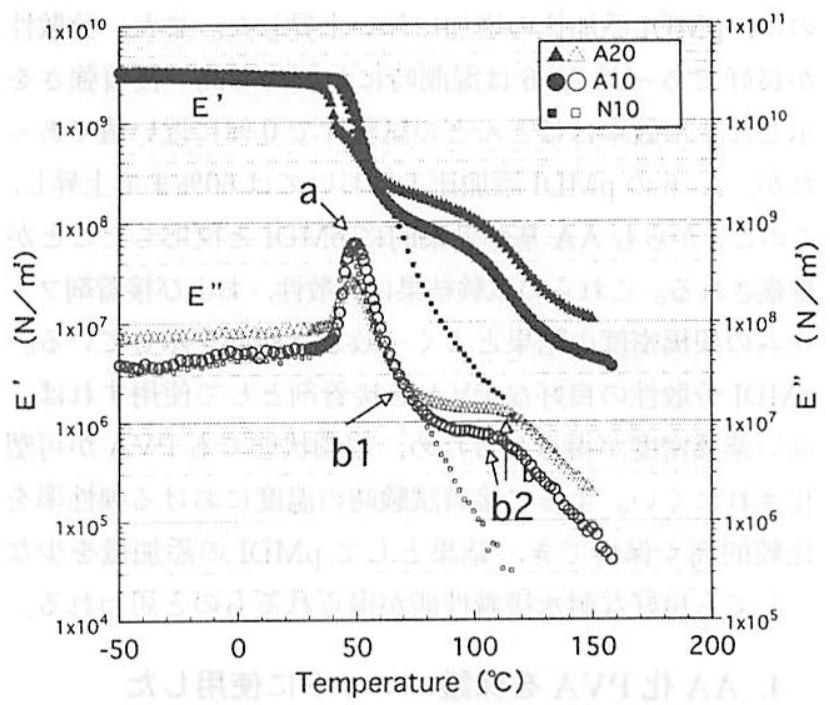

図 $9120^{\circ} \mathrm{C}$ で 2 時間加温した $\mathrm{A} 10$ および $\mathrm{N} 10$ フィルムの 動的粘弾性

示した。しかし， $20^{\circ} \mathrm{Cで} 7$ 日間硬化させた試験片の室温水 3 時間浸せき処理では, A10 の接着性能が N10 のそれを 大きく上回った。加温温度が高くなると耐水接着性能も向 上し, $120^{\circ} \mathrm{C}$ で 2 時間の加温を行うと, 而水接着強さは常 態の半分程度にまで向上した。また, 同条件では A10 は N10 に比べて約 2 倍の接着強さを示した。

\section{5. 結 論}

アセトアセチル (AA) 化PVA の優れた木材接着性能を 解明するため, PVAの重合度や側鎖に導入した疎水基の 量および分布状態を変えた一般 PVA および AA 化 PVA の水溶液を用いて界面活性能, PVA 水溶液の pMDI 分散 性能や木材接着性能を評価した。また, AA 化 PVA を保 護コロイドとした酢酸ビニル樹脂エマルション（EPVAc） を合成してフィルム物性や木材接着性能を検討した結果, 以下のことが明らかとなった。

AA 化 PVA 水溶液は表面張力が低く, 一般 PVA に比 べて水溶液中で油状成分である pMDI な小な粒子に分 散させることが明らかとなった。これに伴いPVA 水溶液 中でのイソシアネート基消費についても AA 化 PVA は優 れた性能を示した。また, pMDIの分散性能が良好な PVA ほど混合フィルムの動的粘弾性の E” ピークが高温側にシ フトし，同時にゴム状平坦部の $\mathrm{E}^{\prime}$ 值が上昇した。中でむ 


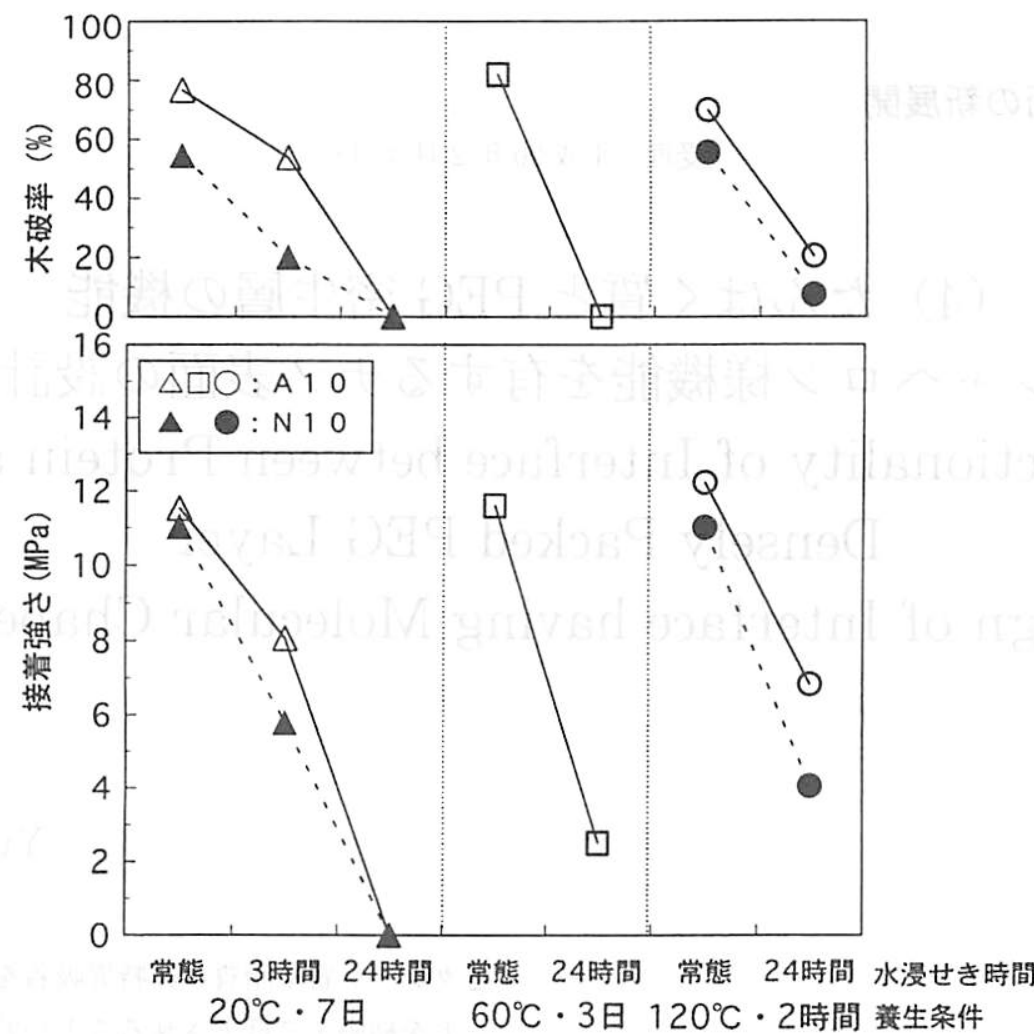

図 10 様々な条件で養生した A10 および N10 の木材接着性能

AA 化 PVA は E”ピークのシフト量が全サンプル中で最 大であった。ガラス転移温度のずれから Nielsenの経験式 を用いて算出した架橋密度とゴム弾性理論により導かれた 式を用いてゴム状平坦部における E’ 值から算出した架橋 密度とを比較したところ，分散性が良いPVA ほどどちら の式から算出された架橋密度も高い值を示した。架橋反応 に関与したPVA 中の官能基の割合 (架橋率) を検討した 結果, 分散性の良い PVA ほど架橋率が高く, 特に AA 化 PVA は架橋率が非常に高かった。また pMDI 添加比が多 くなるほどこの傾向は顕著になった。分散性が良好でフィ ルムの架橋密度が高い PVA ほど高い木材接着性能を示し, 分散性能と木材接着性能には高い相関が認められた。

AA 化 PVA を保護コロイドに用いた EPVAcでは, $120^{\circ} \mathrm{C}$ で 2 時間以上の加温を行うことにより $\mathrm{AA}$ 化 PVA が自己架橋を起こし，PVAのガラス転移に基づく E”ピー クの高温側へのシフトや高温域における E’の低下が抑え られた。AA 化 PVA を使用した EPVAc は耐水接着性能

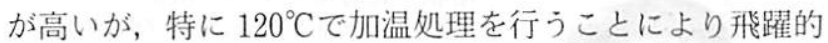
に木材接着性能が向上することが明らかになった。

以上のことから， AA 基は踈水基として優れた界面活性 能を有するだけでなく, 反応性を持つ官能基として油状成 分を水溶液中に分散させ，これが木材接着性能にも大きく 関与していることが明らかとなった。また, EPVAcの保 護コロイドとしても非常に有用なことが明らかとなり，今 後, 木材用接着剤原料としての使用が期待される。

\section{参 考 文 献}

1）由良政昭著：“入門・エマルションの応用”, 高分子刊行会 1988, pp. 18

2) 山田雅章：木材工業，60，320 (2005)

3）黑柳義康，佐藤公治，阿高利明：日本接着学会誌，35，233 (1999)

4) A.Mori, K.Tashiro, K.Makita, M.Takatani, T.Okamoto: J. Wood Sci., 51, 33 (2005)

5) A.Mori, K.Tashiro, K.Makita, M.Takatani, T.Okamoto: J. Wood Sci., 51, 38 (2005)

6）山田雅章，滝 欽二，沾谷光夫：日本接着学会誌，42，2 (2006).

7）山田雅章，前田理恵子，滝 欽二，渋谷光夫：日本接着学会 誌, 42, 15 (2006).

8）山田雅章，前田理恵子，滝 欽二，沾谷光夫：日本接着学会 誌, 42, 1 (2006)

9）山田雅章, 滝 欽二, 吉田弥明, 江崎竜彦：木材学会誌， 53 , 25 (2007)

10）岸真奈美：接着の技術，14, 60（1994）

11）秋山 護：接着, 35, 163 (1991)

12) Tohei Moritani, Yuzuru Fujiwara: Macromolecules, 10 , (3), 532-535 (1977)

13）長野浩一：『ポバール』高分子刊行会

14）高分子学会編：“単量体 II ”, 199, 共立出版 (1977)

15） L. E. Nielsen: 高分子と複合材料の力学的性質，(椒化学同人 (1969)

16） L. E. Nielsen: 高分子の力学的性質，(菞化学同人（1986）

17）滰 欽二, 八木繁和, 山岸祥恭：木材学会誌, 26, 81 (1980)

18）滰 欽二, 富田文一郎, 水町 浩：木材学会誌, 29, 145 (1983) 